\title{
Evaluation of Combustion Toxicity from Various Materials Using a New Testing Apparatus
}

\author{
SHYUITSU YUSA \\ Building Research Institute \\ Ministry of Construction \\ 1 Tatehara, Tsukuba \\ Ibaraki 305, Japan
}

\section{ABSTRACT}

The Building Research Institute is developing an apparatus for toxicity testing of building materials. The toxicity of combustion products of typical materials are evaluated by animal exposure tests using the new apparatus. The weights of the materials when generating combustion products sufficient to cause incapacitation of mice under given exposure conditions (steady - state) are obtained and combined with the time to incapacitation. It is shown that the relative degrees of toxicities of combustion products of materials may be expressed by those values (ECT).

\section{INTRODUCTION}

The new apparatus for testing combustion toxicity was developed at the Building Research Institute, Ministry of Constraction in Japan around 1983. It has been developed in the research program of the United States - Canada - Japan Trilateral Research Group on Toxicity of Combustion Products from Building Materials and Interior Goods (from 1982 FY to 1986 FY). The apparatus is designed to supply air or $\mathrm{N}_{2}$ mixtures in the furnace, and to simulate the condition to which the materials are exposed in real fire.

\section{METHODS}

The materials used for testing were those indicated Table 1. They were made into specimens $10 \mathrm{~cm}$ in diameter, dried in an oven at temperatures of 45 to $55^{\circ} \mathrm{C}$ for at least 24 hours, then left in a desiccator containing silica gel for more than 24 hours, after which they were tested.

The testing apparatus comprises a combustion device and an exposure chamber as shown in Figure 1. The cone guartz combustion tube is held inside a cone radiative electric furnace. The mass loss of the samples during the tests is measured continuously by the load cel.I. From the bottom of quartz tube and around the sample, air is supplied to continue the combustion. At the top of the cone quartz tube, the gasket is set up to make the time to introduce the products arbitrary so that a selected part of the combustion could be introduced to the exposure chamber. The exposure chamber is designed to produce a square wave (Steady - State) 


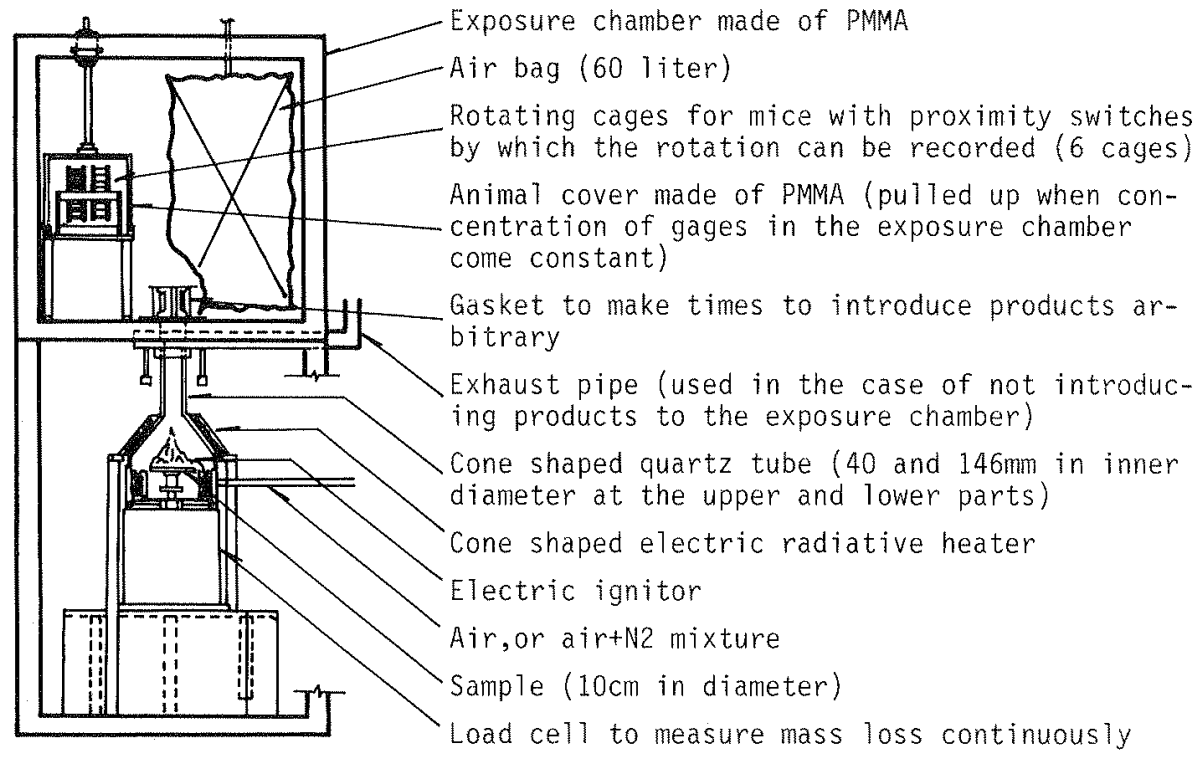

Figure1 Test Apparatus

Table 1. Materials Tested

\begin{tabular}{llcc}
\hline \multicolumn{1}{c}{ Material } & Form & $\begin{array}{c}\text { Thickness } \\
(\mathrm{mm})\end{array}$ & $\begin{array}{c}\text { Density } \\
\left(\mathrm{g} / \mathrm{cm}^{3}\right)\end{array}$ \\
\hline Lauan & Board & 9.8 & $0.50 \sim 0.53$ \\
Insulation board & Board & 9.0 & 0.26 \\
Particle board & Board & 12.5 & $0.61 \sim 0.68$ \\
Melamine resin-impregnated & Rigid sheet & 1.5 & 1.12 \\
$\quad$ sheet & Carpet & 10 & \\
Acrylic & Carpet & 10 & \\
Polyamide(Nylon) & Felt & 10 & 0.20 \\
Wool & Flexible foam & 10 & 0.02 \\
Flexible Polyurethane & Board & 3 & 1.38 \\
Polyvinyl chloride & Fiber & \\
Modacrylic & Flexible sheet & \\
PTFE & & & \\
\hline
\end{tabular}

exposure condition to the animals.

Specifications of the apparatus are described in the following:

(1) The combustion system

$$
\begin{aligned}
& \text { :heating system - } \\
& \text { type) } \\
& \text { : furnace - } \\
& \begin{array}{l}
\text { cone shaped quartz tube (40 mper part, } 164 \mathrm{~mm} \text { inner diameter at } \\
\text { the lower part, } 3 \mathrm{~mm} \text { thick) }
\end{array}
\end{aligned}
$$


:air supply system -.- mechanical supply (air, air $+\mathrm{N}_{2}$ mixture), air temperature control system

:test sample _......... commercial products, horizontal orientation

(2) The exposure system

:exposure method _-_.- static, whole body exposure, 15-30 minutes of exposure, square wave exposure

:animal _.................... species : mouse (dd strain, weight $20 \pm 2 \mathrm{~g}$ )

number: 6

(3) Measurements

:mass loss _-_.......... continuous measurement during the test

:chamber atmosphere -- continuous measurement of the concentrations of $\mathrm{O}_{2}, \mathrm{CO}_{2}, \mathrm{CO}$, and temperature : concentrations of HCN and HCl at a fixed time interval

:effect to animals -.. time to incapacitation, etc.

The combustion products generated from flaming combustion or non flaming combustion are introduced into the exposure chamber for the several duration to make various concentrations of products. The animal cover is pulled up following the constant concentration of the products, and the exposure to 6 animals in revolving cages starts. The conditions of the mice causing the cages to revolve are recorded as electrical pulses by proximity switches. The time to incapacitation is defined as the length of time from the start of exposure until the point that a mouse could no longer make its cage revolve. External radiation levels were mainly $2.5 \mathrm{w} / \mathrm{cm}^{2}$, and partially 3.5 and $4.5 \mathrm{w} / \mathrm{cm}^{2}$. The air supply rates are selected by which the flaming mode is sustained in the minimum rates. However the non flaming mode appeared partially.

The gas concentration inside the exposure chamber is measured by a magnetic type analyzer for $\mathrm{O}_{2}$, and by an infrared analyzer for $\mathrm{CO}_{2}$ and Co. To determine the concentration of hydrogen cyanide in expósure chamber, $100 \mathrm{ml}$ of sample gas was collected every two minutes into a syringe barrel and absorbed in an $0.1 \mathrm{~N}-\mathrm{NaOH}$ solution, and then analyzed by ion chromatography. To determine the concentration of hydrogen chloride in combustion gases, $200 \mathrm{ml}$ of sample gas was collected every two or three minutes into a syringe barrel with approximately 20 $\mathrm{ml}$ of alkaline absorption $(0.1 \mathrm{~N} \mathrm{NaOH})$ and analyzed by ion chromatography. The $\mathrm{CO}, \mathrm{CO}_{2}$, and $\mathrm{O}_{2}$ data and temperature measurements at the animal exposure position were collected by an on - line computer every 6 seconds, as was the weight of the sample. The $\mathrm{COHb}$ value of the blood of the mice is determined by the IL282 CO-OXIMETER, although not for all the cases.

\section{Results and Considerations}

Though the combustion of tested materials was almost near steady state, there were some materials which had both flaming and non flaming mode in one test run. These were MRIS, Acrylic, and Modacrylic. In the case of PVC, there was some scatter in formation of flame. The test results of the various materials are indicated in Table 2 .

The exposure method used in this study is, as mentioned above, intended to be a square wave exposure. However, although the steady state was obtained in the case of $\mathrm{O}_{2}, \mathrm{CO}_{2}$, and $\mathrm{CO}$, there was the difficulty in maintaining the HCI concentration constant 1). In the case of HCN, Figure 
Table 2. Results for animal exposure test

\begin{tabular}{|c|c|c|c|c|c|c|c|c|c|c|c|c|c|}
\hline Material & $\left(\mathrm{w} / \dot{\mathrm{q}}_{e}^{\prime \prime}{ }_{\mathrm{cm}}^{2}\right)$ & $\frac{\operatorname{Air}}{(1 / \min )}$ & $\begin{array}{l}\text { Comb. } \\
\text { mode }\end{array}$ & $\begin{array}{l}\text { Time } \\
\text { to Ig } \\
\text { (sec) }\end{array}$ & $\begin{array}{l}\text { Mass } \\
\text { concent } \\
(\mathrm{mg} / 1)\end{array}$ & $\frac{\text { Ave. } 0}{\text { co }}$ & 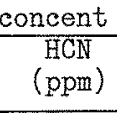 & $\frac{\text { of gases }}{\text { HCl }}$ & $\begin{array}{l}\mathrm{CO} \\
/ \\
\mathrm{CO}_{2}\end{array}$ & $\begin{array}{l}\text { Ave. time to } \\
\text { incapacitation } \\
\text { (min) }\end{array}$ & $\begin{array}{c}\mathrm{ECT} \\
\left(\mathrm{mg} / \mathrm{I}^{\bullet} \mathrm{min}\right)\end{array}$ & $\begin{array}{r}\mathrm{COHb} \\
(\%)\end{array}$ & Mortality \\
\hline Lauan & 2.50 & $\begin{array}{l}8.0 \\
6.0+ \\
5.6 \mathrm{~N}_{2}\end{array}$ & $\begin{array}{l}\mathrm{F} \\
\mathrm{F} \\
\mathrm{F} \\
\mathrm{F} \\
\mathrm{B} \\
\mathrm{F} \\
\mathrm{F}\end{array}$ & $\begin{array}{l}35 \\
35 \\
35 \\
45 \\
40 \\
30 \\
30\end{array}$ & $\begin{array}{r}81.80 \\
144.24 \\
72.96 \\
56.24 \\
115.76 \\
62.80 \\
45.60\end{array}$ & $\begin{array}{l}0.72 \\
1.24 \\
0.68 \\
0.45 \\
1.26 \\
0.64 \\
0.47\end{array}$ & $\begin{array}{l}- \\
- \\
- \\
- \\
-\end{array}$ & $\begin{array}{l}- \\
- \\
- \\
- \\
-\end{array}$ & $\begin{array}{l}0.19 \\
0.20 \\
0.19 \\
0.18 \\
0.33 \\
0.26 \\
0.25\end{array}$ & $\begin{array}{r}4.64 \pm 1.29 \\
2.03 \pm 0.42 \\
4.82 \pm 1.59 \\
9.06 \pm 4.16 \\
1.94 \pm 0.33 \\
4.43 \pm 0.76 \\
12.50 \pm 4.92\end{array}$ & $\begin{array}{l}379.37 \\
292.81 \\
351.67 \\
509.53 \\
224.57 \\
278.20 \\
572.74\end{array}$ & $\begin{array}{l}- \\
- \\
- \\
- \\
-\end{array}$ & $\begin{array}{l}3 / 6 \\
6 / 6 \\
6 / 6 \\
1 / 6 \\
6 / 6 \\
6 / 6 \\
3 / 6\end{array}$ \\
\hline INSLBD & $\begin{array}{l}2.69 \\
2.64 \\
2.59 \\
2.63 \\
2.52 \\
2.59 \\
2.60 \\
2.65 \\
2.72\end{array}$ & $\begin{array}{l}10.0 \\
8.0\end{array}$ & $\begin{array}{l}F \\
F \\
F \\
F \\
F \\
F \\
F \\
F \\
F\end{array}$ & $\begin{array}{r}10 \\
5 \\
10 \\
10 \\
10 \\
15 \\
15 \\
15 \\
10\end{array}$ & $\begin{array}{r}65.36 \\
86.24 \\
54.80 \\
46.00 \\
106.96 \\
86.96 \\
98.72 \\
102.24 \\
111.60\end{array}$ & $\begin{array}{l}0.72 \\
1.00 \\
0.65 \\
0.42 \\
0.45 \\
0.34 \\
0.85 \\
0.96 \\
1.01\end{array}$ & $\begin{array}{l}- \\
- \\
- \\
- \\
- \\
- \\
-\end{array}$ & $\begin{array}{l}- \\
- \\
- \\
- \\
- \\
- \\
-\end{array}$ & $\begin{array}{l}0.34 \\
0.39 \\
0.37 \\
0.39 \\
0.08 \\
0.08 \\
0.20 \\
0.24 \\
0.24\end{array}$ & $\begin{array}{r}4.38 \pm 0.52 \\
3.99 \pm 0.71 \\
5.50 \pm 1.04 \\
12.61 \pm 3.54 \\
6.61 \pm 1.80 \\
15.83 \pm 6.54 \\
2.98 \pm 0.37 \\
3.17 \pm 0.01 \\
2.97 \pm 0.41\end{array}$ & $\begin{array}{r}286.28 \\
344.10 \\
301.40 \\
580.06 \\
707.01 \\
1376.58 \\
294.20 \\
324.10 \\
331.50\end{array}$ & $\begin{array}{c}83.60 \\
83.26 \\
79.68 \\
64.03 \\
70.60 \\
57.10 \\
- \\
- \\
-\end{array}$ & $\begin{array}{l}5 / 6 \\
6 / 6 \\
5 / 6 \\
2 / 6 \\
6 / 6 \\
3 / 6 \\
6 / 6 \\
6 / 6 \\
6 / 6\end{array}$ \\
\hline PTCBD & $\begin{array}{l} \\
2.72 \\
2.75 \\
2.57 \\
2.79\end{array}$ & 10 & $\begin{array}{l}F \\
F \\
F \\
F \\
F \\
F \\
F \\
F \\
F\end{array}$ & $\begin{array}{l}- \\
50 \\
60 \\
50 \\
55 \\
50 \\
50 \\
60 \\
55\end{array}$ & $\begin{array}{r}105.80 \\
88.70 \\
41.92 \\
19.92 \\
15.76 \\
33.76 \\
65.00 \\
40.40 \\
43.84\end{array}$ & $\begin{array}{l}1.24 \\
1.01 \\
0.54 \\
0.36 \\
0.25 \\
0.22 \\
0.75 \\
0.43 \\
0.53\end{array}$ & $\begin{array}{c}- \\
- \\
- \\
- \\
- \\
41 \\
195 \\
110 \\
103\end{array}$ & $\begin{array}{l}- \\
- \\
- \\
- \\
- \\
- \\
-\end{array}$ & $\begin{array}{l}0.35 \\
0.29 \\
0.30 \\
0.27 \\
0.26 \\
0.27 \\
0.28 \\
0.26 \\
0.28\end{array}$ & $\begin{array}{r}1.18 \pm 0.17 \\
1.03 \pm 0.19 \\
2.95 \pm 0.83 \\
7.09 \pm 3.15 \\
10.88 \pm 4.87 \\
19.70 \pm 2.86 \\
2.44 \pm 0.63 \\
5.79 \pm 1.44 \\
4.36 \pm 1.73\end{array}$ & $\begin{array}{r}124.84 \\
91.36 \\
123.66 \\
141.23 \\
171.47 \\
665.07 \\
158.60 \\
233.92 \\
191.14\end{array}$ & $\begin{array}{c}- \\
- \\
- \\
- \\
- \\
45.62 \\
55.00 \\
67.02 \\
59.63\end{array}$ & $\begin{array}{l}6 / 6 \\
6 / 6 \\
6 / 6 \\
6 / 6 \\
6 / 6 \\
0 / 6 \\
6 / 6 \\
6 / 6 \\
4 / 4\end{array}$ \\
\hline MRIS & $\begin{array}{l}2.27 \\
2.59 \\
2.89\end{array}$ & 6.0 & $\begin{array}{c}\mathrm{NE}+\mathrm{F}^{2} \\
\mathrm{~F} \\
\mathrm{NF}\end{array}$ & $\begin{array}{l}(45) \\
45 \\
-\end{array}$ & $\begin{array}{l}50.20 \\
62.50 \\
43.90\end{array}$ & $\begin{array}{l}0.91 \\
0.34 \\
0.56\end{array}$ & $\begin{array}{r}159 \\
46 \\
135\end{array}$ & $\begin{array}{l}- \\
- \\
-\end{array}$ & $\begin{array}{l}1.27 \\
0.53 \\
0.65\end{array}$ & $\begin{array}{r}2.13 \pm 0.33 \\
11.22 \pm 3.25 \\
4.15 \pm 0.98\end{array}$ & $\begin{array}{l}106.93 \\
701.25 \\
182.19\end{array}$ & $\begin{array}{l}64.80 \\
62.90 \\
64.90\end{array}$ & $\begin{array}{l}6 / 6 \\
4 / 6 \\
6 / 6\end{array}$ \\
\hline
\end{tabular}




\begin{tabular}{|c|c|c|c|c|c|c|c|c|c|c|c|c|c|}
\hline Material & $\left(\mathrm{w} / \dot{\mathrm{cm}}^{\prime \prime}{ }^{2}\right)$ & $\frac{\text { Air }}{(1 / \min )}$ & $\begin{array}{l}\text { Comb. } \\
\text { mode }\end{array}$ & $\begin{array}{l}\text { Time } \\
\text { to Ig } \\
\text { (sec) }\end{array}$ & $\begin{array}{l}\text { Mass } \\
\text { concent } \\
\text { (mg/l) }\end{array}$ & $\frac{\text { Ave. }}{\text { Co }}$ & 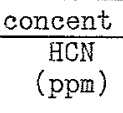 & $\frac{\text { of gases }}{\text { HCl }}$ & $\begin{array}{l}\mathrm{CO} \\
1 \\
\mathrm{CO}_{2}\end{array}$ & $\begin{array}{l}\text { Ave. time to } \\
\text { incapacitation } \\
\quad \text { (min) }\end{array}$ & $\frac{\mathrm{ECT}}{(\mathrm{mg} / \mathrm{I} \cdot \mathrm{min})}$ & $\begin{array}{c}\mathrm{COHb} \\
(\%)\end{array}$ & Mortality \\
\hline Acrylie & $\begin{array}{l}2.64 \\
2.62 \\
2.80 \\
2.72\end{array}$ & 6.0 & $\begin{array}{c}\mathrm{F}+\mathrm{NF} \\
\mathrm{F} \\
F \\
F\end{array}$ & $\begin{array}{l}10 \\
10 \\
10 \\
10\end{array}$ & $\begin{array}{l}10.40 \\
14.60 \\
17.00 \\
12.20\end{array}$ & $\begin{array}{l}0.06 \\
0.09 \\
0.09 \\
0.08\end{array}$ & $\begin{array}{l}231 \\
342 \\
351 \\
244\end{array}$ & $\begin{array}{l}- \\
- \\
-\end{array}$ & $\begin{array}{l}0.23 \\
0.20 \\
0.25 \\
0.28\end{array}$ & $\begin{array}{l}3.41 \pm 1.17 \\
1.45 \pm 0.27 \\
1.52 \pm 0.14 \\
1.85 \pm 0.28\end{array}$ & $\begin{array}{l}35.46 \\
21.23 \\
25.84 \\
22.57\end{array}$ & $\begin{array}{c}17.60 \\
5.90 \\
9.20 \\
-\end{array}$ & $\begin{array}{l}6 / 6 \\
6 / 6 \\
6 / 6 \\
6 / 6\end{array}$ \\
\hline Nylon & $\begin{array}{l}2.74 \\
2.64 \\
2.52 \\
2.70 \\
2.79\end{array}$ & 6.0 & $\begin{array}{l}F \\
F \\
F \\
F \\
F\end{array}$ & $\begin{array}{l}60 \\
80 \\
58 \\
75 \\
75\end{array}$ & $\begin{array}{l}45.00 \\
27.80 \\
28.80 \\
23.80 \\
23.40\end{array}$ & $\begin{array}{l}0.28 \\
0.19 \\
0.18 \\
0.16 \\
0.13\end{array}$ & $\begin{array}{l}343 \\
184 \\
244 \\
238 \\
133\end{array}$ & $\begin{array}{l}- \\
- \\
- \\
-\end{array}$ & $\begin{array}{l}0.27 \\
0.23 \\
0.19 \\
0.19 \\
0.19\end{array}$ & $\begin{array}{l}2.34 \pm 0.91 \\
3.78 \pm 2.09 \\
1.99 \pm 0.55 \\
2.03 \pm 0.04 \\
6.73 \pm 1.32\end{array}$ & $\begin{array}{r}105.30 \\
105.10 \\
57.30 \\
48.30 \\
157.50\end{array}$ & $\begin{array}{l}27.50 \\
29.80 \\
27.50 \\
36.40 \\
20.20\end{array}$ & $\begin{array}{l}6 / 6 \\
1 / 6 \\
6 / 6 \\
4 / 6 \\
1 / 6\end{array}$ \\
\hline Wool & $\begin{array}{l}2.60 \\
2.87 \\
2.95 \\
2.69\end{array}$ & 10.0 & $\begin{array}{l}\mathrm{F} \\
\mathrm{F} \\
\mathrm{F} \\
\mathrm{F}\end{array}$ & $\begin{array}{r}0 \\
10 \\
7 \\
5\end{array}$ & $\begin{array}{l}36.60 \\
13.20 \\
13.50 \\
58.70\end{array}$ & $\begin{array}{l}0.09 \\
0.04 \\
0.07 \\
0.11\end{array}$ & $\begin{array}{l}312 \\
185 \\
304 \\
306\end{array}$ & $\begin{array}{l}- \\
- \\
-\end{array}$ & $\begin{array}{l}0.06 \\
0.06 \\
0.10 \\
0.07\end{array}$ & $\begin{array}{l}2.29 \pm 0.75 \\
5.00 \pm 1.88 \\
2.05 \pm 1.09 \\
1.68 \pm 1.09\end{array}$ & $\begin{array}{l}83.80 \\
66.00 \\
27.70 \\
98.60\end{array}$ & $\begin{array}{r}3.30 \\
12.00 \\
4.50 \\
7.50\end{array}$ & $\begin{array}{l}6 / 6 \\
2 / 6 \\
6 / 6 \\
6 / 6\end{array}$ \\
\hline FPU & $\begin{array}{l}2.72 \\
2.64 \\
2.75\end{array}$ & 6.0 & $\begin{array}{l}\mathrm{F} \\
\mathrm{F} \\
\mathrm{F}\end{array}$ & $\begin{array}{l}0 \\
0 \\
0\end{array}$ & $\begin{array}{l}13.76 \\
26.00 \\
35.92\end{array}$ & $\begin{array}{l}0.20 \\
0.41 \\
0.60\end{array}$ & $\begin{array}{r}61 \\
110 \\
174\end{array}$ & $\begin{array}{l}- \\
-\end{array}$ & $\begin{array}{l}0.21 \\
0.34 \\
0.37\end{array}$ & $\begin{array}{r}14.68 \pm 4.64 \\
5.97 \pm 1.86 \\
2.34 \pm 0.58\end{array}$ & $\begin{array}{r}202.00 \\
155.20 \\
84.10\end{array}$ & $\begin{array}{l}47.10 \\
65.10 \\
61.40\end{array}$ & $\begin{array}{l}0 / 6 \\
6 / 6 \\
6 / 6\end{array}$ \\
\hline PVC & $\begin{array}{l}2.34 \\
2.44 \\
2.50 \\
2.60\end{array}$ & 15.0 & $\begin{array}{l}F \\
F \\
F \\
F\end{array}$ & $\begin{array}{l}90 \\
85 \\
80 \\
75\end{array}$ & $\begin{array}{l}- \\
- \\
-\end{array}$ & $\begin{array}{l}0.31 \\
0.35 \\
0.33 \\
0.16\end{array}$ & $\begin{array}{l}- \\
- \\
-\end{array}$ & $\begin{array}{r}5800 \\
9750 \\
12250 \\
5800\end{array}$ & $\begin{array}{l}0.22 \\
0.27 \\
0.35 \\
0.41\end{array}$ & $\begin{array}{r}10.66 \pm 3.70 \\
5.95 \pm 1.59 \\
5.24 \pm 1.36 \\
15.22 \pm 7.96\end{array}$ & $\begin{array}{l}- \\
- \\
-\end{array}$ & $\begin{array}{l}- \\
- \\
-\end{array}$ & $\begin{array}{l}6 / 6 \\
6 / 6 \\
6 / 6 \\
6 / 6\end{array}$ \\
\hline Modacrylic & $\begin{array}{l}2.67 \\
2.62 \\
2.57 \\
2.54\end{array}$ & 6.0 & $\begin{array}{l}\mathrm{F} \\
\mathrm{F}+\mathrm{NF} \\
\mathrm{F}+\mathrm{NF} \\
\mathrm{NF}\end{array}$ & $\begin{array}{l}25 \\
40 \\
40 \\
-\end{array}$ & $\begin{array}{l}16.72 \\
15.04 \\
16.00 \\
20.40\end{array}$ & $\begin{array}{l}0.03 \\
0.03 \\
0.03 \\
0.02\end{array}$ & $\begin{array}{l}117 \\
397 \\
382 \\
526\end{array}$ & $\begin{array}{l}- \\
- \\
-\end{array}$ & $\begin{array}{l}0.06 \\
0.08 \\
0.08 \\
0.23\end{array}$ & $\begin{array}{l}3.62 \pm 1.98 \\
1.24 \pm 0.22 \\
1.21 \pm 0.24 \\
1.22 \pm 0.11\end{array}$ & $\begin{array}{l}60.50 \\
18.70 \\
19.40 \\
24.40\end{array}$ & $\begin{array}{l}7.10 \\
1.00 \\
0.70 \\
0.00\end{array}$ & $\begin{array}{l}2 / 6 \\
6 / 6 \\
6 / 6 \\
6 / 6\end{array}$ \\
\hline PTFE & $\begin{array}{l}2.74 \\
4.77 \\
3.84\end{array}$ & 6.0 & $\underset{\mathrm{NE}}{\overline{\mathrm{F}}}$ & $\overline{30}$ & $\begin{array}{l}5.60 \\
6.67\end{array}$ & $\begin{array}{l}- \\
0.01 \\
0.02\end{array}$ & $\begin{array}{l}- \\
-\end{array}$ & $\begin{array}{l}- \\
- \\
-\end{array}$ & $\begin{array}{l}- \\
-\end{array}$ & $\begin{array}{c}- \\
24.26 \pm 2.86 \\
9.72 \pm 2.39\end{array}$ & $\begin{array}{c}- \\
135.90 \\
64.80\end{array}$ & $\begin{array}{c}0.00 \\
- \\
0.70\end{array}$ & $\begin{array}{l}0 / 6 \\
0 / 6 \\
5 / 6\end{array}$ \\
\hline
\end{tabular}


2 shows that the concentration falls by degrees but not so much as is the case of $\mathrm{HCl}$.

With regard to the test results of various materials, the relationship between mass concentrations (mass loss/chamber volume;mg/l) and average times to incapacitation of mice, and also average concentrations of gases, are indicated in Figures 3 through 7 . In the Figure. 3 the result when the oxygen partial pressure is varied is also indicated. It might be learned that low oxygen concentration increased $\mathrm{CO}$ generation from the material and resulted in shortening the times to incapacitaiton of mice. However, the difference between the two is not so much that there needs more detailed study for a clear conclusion.

Wood based materials such as Lauan, INSLBD, and PATCBD combusted relatively stabilized so that correlation between the mass concentration and gas concentration is good as shown in Figures 3 through 5. And it can explain the variation of the time to incapacitation. Compared with those materials, synthetic materials and wool show some scatter in combustion. Among these, FPU shows relatively clear results as indicated in Figure 6 . With regard to the PTFE, it did not decompose at the $2.7 \mathrm{w} / \mathrm{cm}^{2}$ heating, but decomposed at $3.8 \mathrm{w} / \mathrm{cm}^{2}(\mathrm{NF})$ and $4.8 \mathrm{w} / \mathrm{cm}^{2}$ (F) as shown in Figure 7 . In any case there needs further consideration on combustion.

In the combustion toxicity field, the $L_{50}$ is commonly used and the $\operatorname{LCT}_{50}(\mathrm{mg} / \mathrm{l} \cdot \mathrm{min})$ is used to compare materials. In this study, using the concept, the $\mathrm{BCT}$ which is obtained by multiplying mass concentration by time to incapacitation is shown in Table 2 and indicated in Figure 8. As a matter of course, it may not be possible to compare with LCT directly. However, it is thought the method in this present study, although approximate, is useful in comparison of materials. From the ECT value, materials which show high toxicity are modacrylic $(F+N F, N F)$ and acrylic(F), and their ECTs are around $20 \mathrm{mg} / \mathrm{l} \mathrm{min}$. Modacrylic(F), PTFE(NF), and wool(F) showed roughly equal toxicity and ECTs are around $70 \mathrm{mg} / 1 \mathrm{~min}$, followed by $\operatorname{Nylon}(\mathrm{F}), \operatorname{MRIS}(\mathrm{NF}+\mathrm{F}), \mathrm{FPU}(\mathrm{F})$, and PTFE(F) with $100150 \mathrm{mg} / 1$ min of ETC. The toxicity of PATCBD(F) is higher than natural wood such as lauan(F) and INSLBD(F). In the case of MRIS(F), it showes lower toxicity than natural wood.

In the case of evaluating the toxicity of the fire effluents of a material by causing the test animal to inhale it until some kind of symptom appears, there will be various factors for variation such as scatter in the animals themselves. For example, the condition of generation of toxic products will vary due to variation in combustion rate of the sample according to the shape and size of the sample. A more accurate method of evaluation of toxicity must await further research for development. However, it is thought the method of evaluation by the new apparatus as in this present study is fairly effective for discussion of the toxicity of materials. 


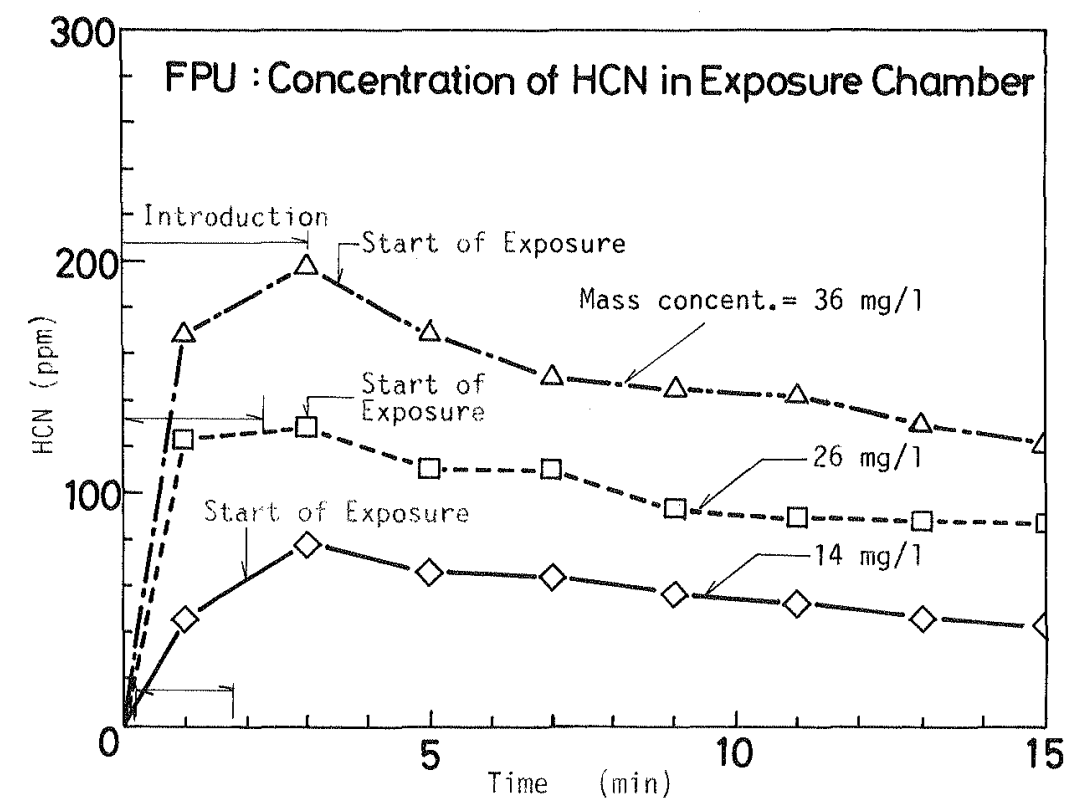

Figure 2 Concentration of $\mathrm{HCN}$ in exposure chamber.

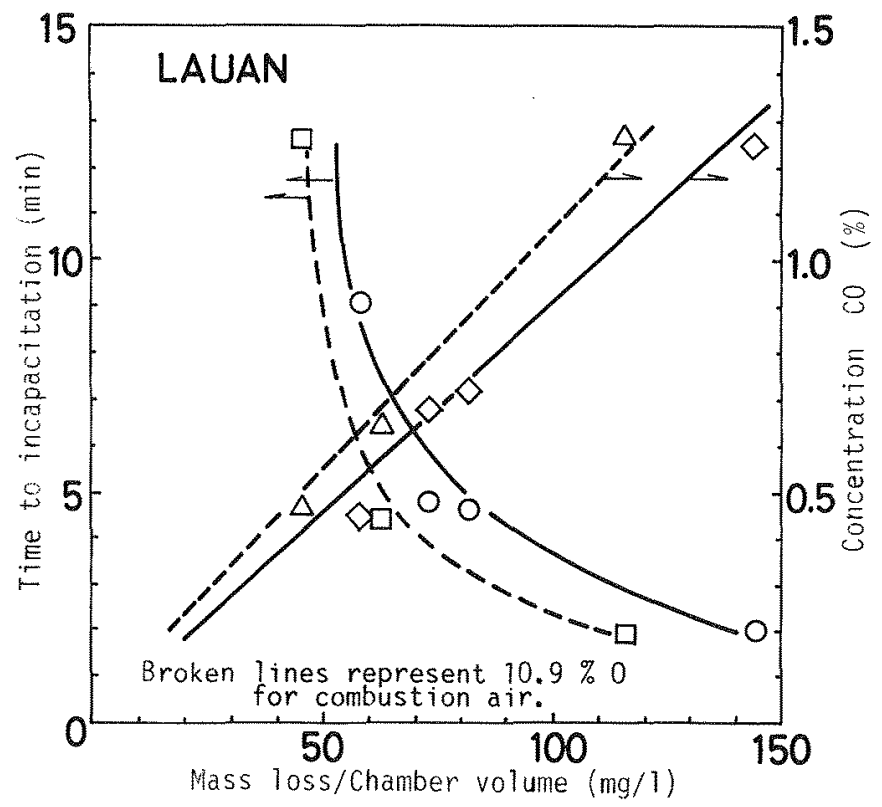

Pigure 3 Result of animal exposure test for lauan. 


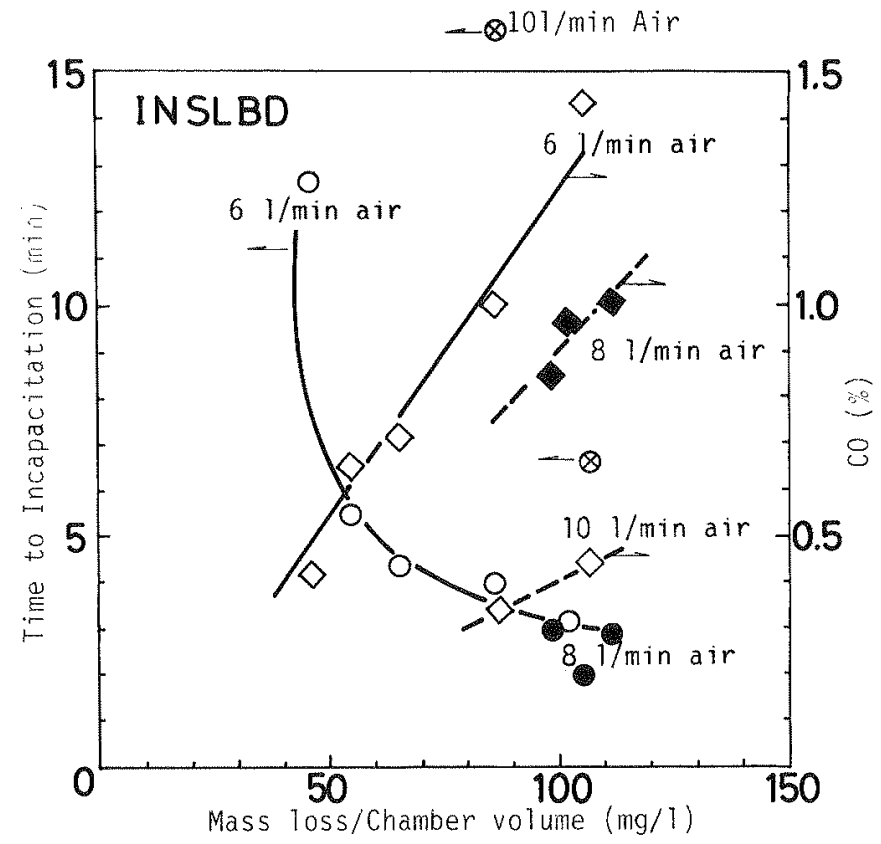

Figure 4 Result of animal exposure test for insulation board.

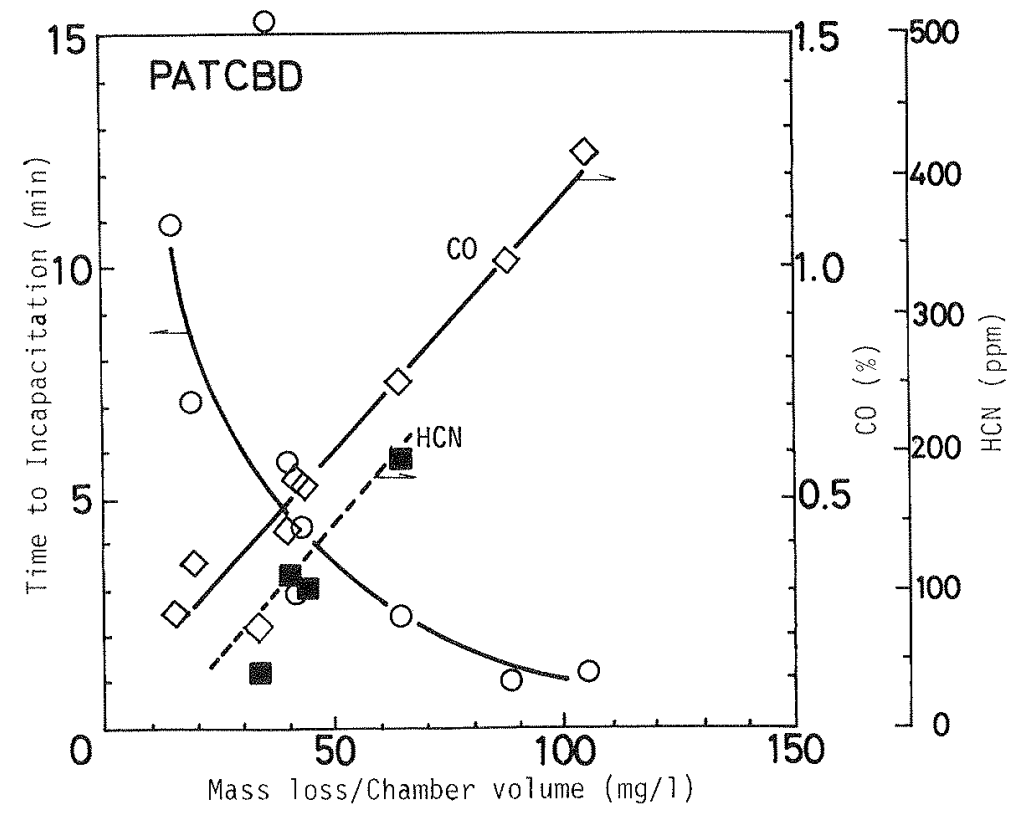

Figure 5 Result of animal exposure test for particle board. 


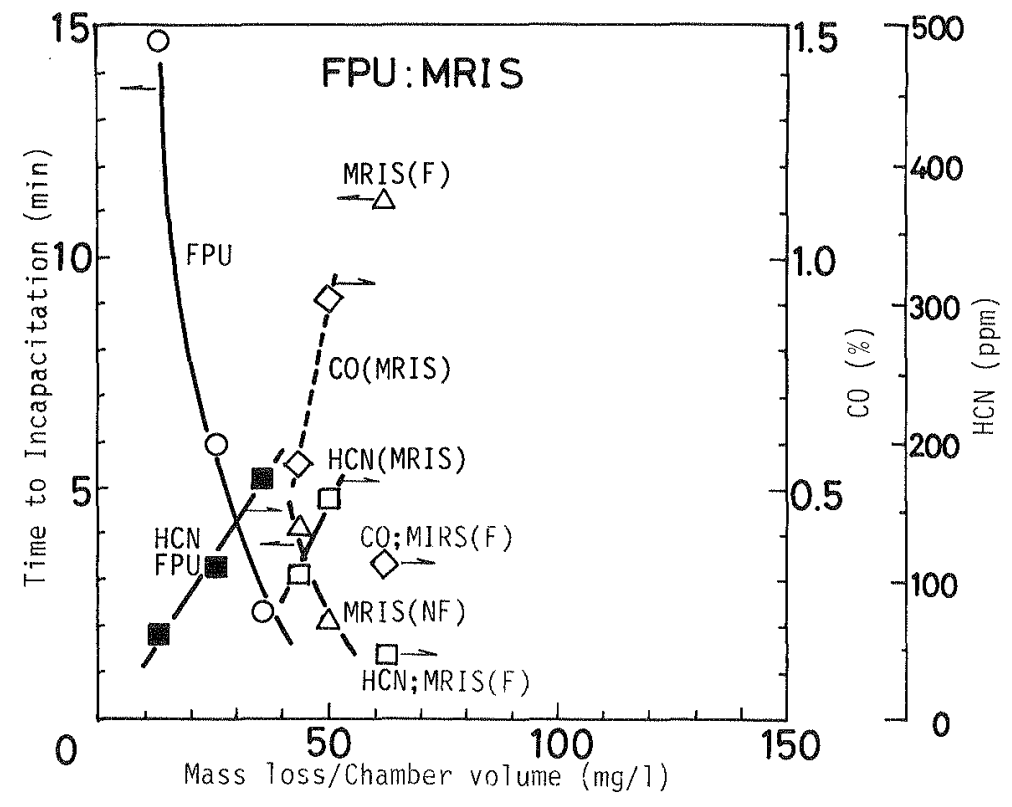

Figure 6 Results of animal exposure test for FPU and MRIS.

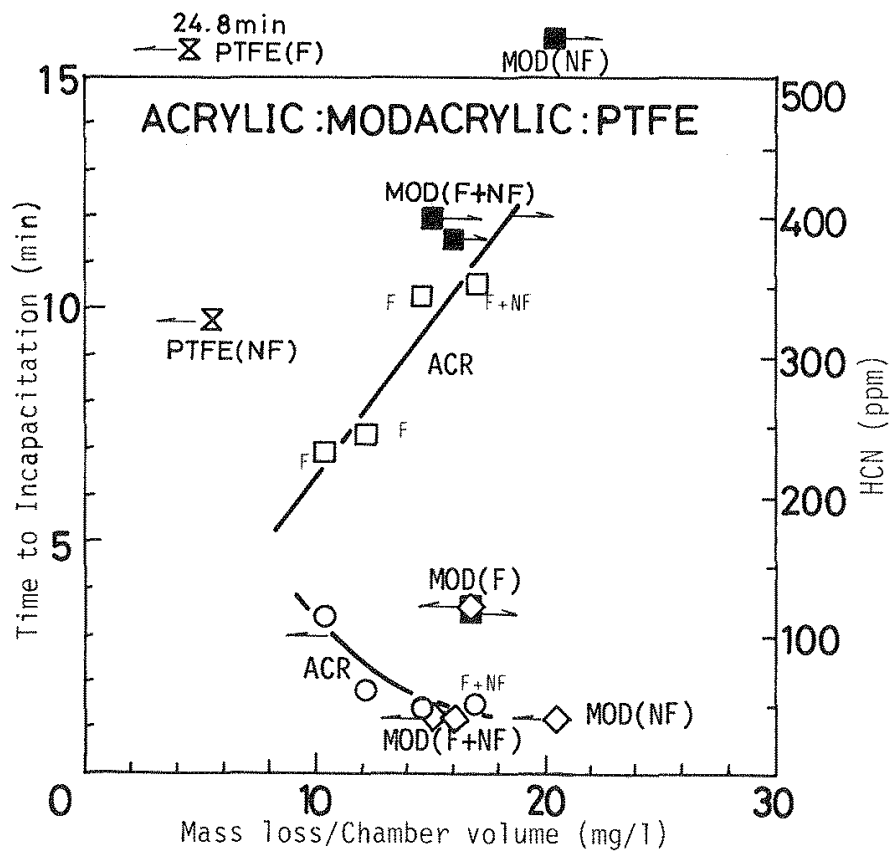

Figure 7 Results of animal exposure test for acrylic, MOD and PTFE. 


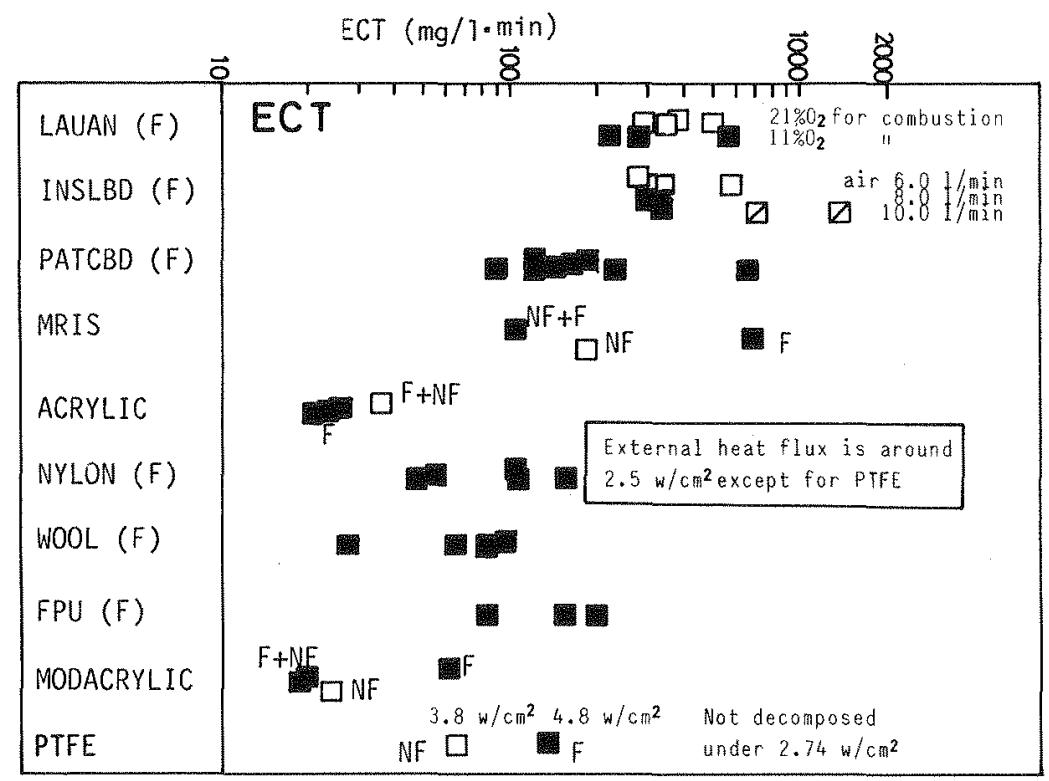

Figure 8 ECT value of each material.

\section{CONCLUSIONS}

Using the newly developed testing apparatus for toxicity of fire effluents, the following results for various materials were obtained.

(1) The steady state animal exposure was obtained in the case of $0_{2}$, $\mathrm{CO}_{2}$, and $\mathrm{CO}$, and almost for $\mathrm{HCN}$. There was the difficulty in maintaing HCl concentration constant.

(2) The correlation between the mass concentration and gas concentration for wood based materials was good. Compared with those materials, synthetic materials showed some scatter in combustion.

(3) The toxicity of fire effluents from materials were compared using ECT values of each material. The order of Toxicity was modacrylic $(\mathrm{F}+\mathrm{NF}, \mathrm{NF})$, acrylic $(\mathrm{F})>\operatorname{PTFE}(\mathrm{NF}), \operatorname{nylon}(\mathrm{F}), \operatorname{wool}(\mathrm{F}),>\operatorname{MRIS}(\mathrm{NF}+\mathrm{F})$, $\operatorname{FPV}(F), \operatorname{PATCBD}(\mathbb{F})>\operatorname{lauan}(F), \operatorname{INSLBD}(F)$.

\section{References}

1) S. Yusa, Toxicity testing of fire effluents, Proceedings of the 3 th UJNR Panel on Fire Research and Safety, 13-21 May, 1985 